\title{
Prevalence of urinary incontinence in reproductive women and its impact on quality of life
}

\section{G. K. Poomalar*, Priyadharshini M.}

Department of Obstetrics and Gynecology, Sri Manakula Vinayagar Medical College and Hospital, Pondicherry, India.

Received: 16 July 2015

Accepted: 14 August 2015

\author{
*Correspondence: \\ Dr. G. K. Poomalar, \\ E-mail: poomalarpragash@gmail.com
}

Copyright: () the author(s), publisher and licensee Medip Academy. This is an open-access article distributed under the terms of the Creative Commons Attribution Non-Commercial License, which permits unrestricted non-commercial use, distribution, and reproduction in any medium, provided the original work is properly cited.

\begin{abstract}
Background: Urogenital problems are more common in the female population. Among them urinary incontinence is a common problem. It has significant impact on the physical, psychological and socio-economic aspects of life. The aim of our study is to estimate the proportion of women with urinary incontinence in reproductive age groups and to assess the impact of urinary incontinence on quality of life.

Methods: This cross sectional study was conducted among 404 women aged between 20 - 45 years. Following data such as socio-demographic characteristics, urinary symptoms and obstetric history, height and weight measurements were recorded. Among those with incontinence, King's Health Questionnaire was used to evaluate severity of affection.

Results: The prevalence of urinary incontinence was $34.1 \%$ in our study. Out of them $73.2 \%$ had mild incontinence, $19.6 \%$ had moderate incontinence and $7.2 \%$ had severe incontinence. Those with urinary incontinence had significantly more amount of health affection than those without incontinence (X2 value -152 , $\mathrm{P}$ value -0.000 ). In those with moderate incontinence, $>95 \%$ had physical activity limitation and social limitation. In those with severe incontinence, $90 \%$ had physical activity restriction, social limitation, emotional affection and sleep deprivation.

Conclusions: The prevalence of urinary incontinence was $34.1 \%$. Urinary incontinence had higher impact on emotional and social well-being. Awareness has to be created about available treatment options among women.
\end{abstract}

Keywords: Urinary incontinence, Quality of life, King's Health questionnaire

\section{INTRODUCTION}

Urogenital problems are more common in the female population. Among them, urinary incontinence is a common and distressing problem. It has significant impact on the physical and psychological aspects of life. Urinary incontinence (UI) is defined by the International Continence Society as the involuntary loss of urine that is a social or hygienic problem to the individual. ${ }^{1}$ Though UI make the women embarrassing and frustrating, they do not consult a doctor. It is because of shyness and lack of motivation particularly among women living in semiurban and rural areas. Some women have no free time to make an appointment with a specialist. Some of them consider it as normal phenomena with increasing age. Most of them tolerate the problem for long and come for consultation only when they become severe. UI is highly prevalent in females than in males. ${ }^{2}$ The reason for higher prevalence in females is due to postmenopausal decline in estrogen levels. This leads to urogenital atrophy, which results in urgency and urge incontinence. ${ }^{3}$ Weakness of the muscles in the pelvic floor may result in hyper mobility of the bladder base, predisposing the individual to stress urinary incontinence (SUI). ${ }^{4}$ Another important and modifiable factor is the trauma to the pelvic supports during vaginal deliveries and obstetric surgeries. ${ }^{5,6}$ 
Incontinence varies in degree of severity from patient to patient. So far, there are many researches, evaluating the prevalence of UI in females. Only few studies were focused on evaluating the impact of UI on quality of life (QoL) in women. The aim of this study is to estimate the proportion of women with UI in reproductive age groups and to assess the impact of UI on quality of life.

\section{METHODS}

A cross sectional study was conducted in Sri Manakula Vinayagar Medical College and Hospital, Pondicherry, India from June 2014 to September 2014. The study was done in 404 women aged between 20 - 45 years who accompany the patients attending our hospital. Considering the proportion of UI among middle aged women (20-45 years) as 30-40\%, at $95 \%$ CI (confidence interval), the sample size was 369. Considering nonresponse rate as $10 \%$, the final sample size was 404 (calculated using open epi software version 2.3). This study was done in accordance with the ethical standards of the research committee after getting ethical committee clearance. An informed written consent was obtained from each patient before this study was conducted. Following data such as socio-demographic factors, urinary symptoms and obstetric history, height and weight measurements were recorded.

Among those with UI, degree of incontinence is assessed by calculating severity index. A severity index was calculated by multiplying the reported frequency and the amount of leakage. There are four levels in reported frequency: 1 . Less than once a month; 2 . One or several times a month; 3 . One or several times a week; 4 . every day and/or night; There are two levels in amount of leakage: 1. Drops or little; 2. More. The resulting index value was further categorized into slight (1-2), moderate (3-4), and severe (6-8). ${ }^{7}$ To assess the QoL affection by UI, King's Health Questionnaire (KHQ) was used. ${ }^{8}$ The KHQ contains 3 parts. All 3 parts together contain 9 domains and 21 sub items within it. Nine domains in part I \& II are general health perception, UI impact, role limitations, physical limitations, social limitations, personal relationships, emotions, sleep/energy and severity measures. 5-point Likert scale was used for the general health perceptions domain. 4-point Likert scale plus a not applicable option was used for the personal relationships domain. 4-point Likert scale was used for the seven other domains. With the formula provided, scores for each domain is calculated. The scores range from 0 to 100 . Higher the score, the worst the QoL related to that domain. Part III is about list of 10 bladder problems. For assessing the severity of bladder problems, 3 -point Likert scale was used. The score of all 10 bladder problems are added which gives total score ranging from 0 to 30 . Chi square test was used to analyze the association of causative factor with prevalence of UI. Percentages were used to assess the impact of UI on QoL.

\section{RESULTS}

The prevalence of UI was $34.1 \%$ in our study. Out of them $73.2 \%$ had mild incontinence, $19.6 \%$ had moderate incontinence and $7.2 \%$ had severe incontinence. UI prevalence is significantly higher in those with parity $\geq 2$ than those with nullipara or para $1\left(\mathrm{X}^{2}\right.$ value $-12.1, \mathrm{P}$ value -0.007) (Table 1).

Table 1: Prevalence of UI in relation to parity.

\begin{tabular}{|llll|}
\hline Parity & $\begin{array}{l}\text { Urinary } \\
\text { incontinence } \\
+ \\
(\mathrm{n}=138)\end{array}$ & $\begin{array}{l}\text { No } \\
\text { incontinence } \\
(\mathrm{n}=266)\end{array}$ & $\begin{array}{l}\mathrm{X}^{2} \\
\text { value }\end{array}$ \\
\hline Nulliparous & 3 & 19 & -12.1 \\
\hline 1 & 14 & 53 & $\mathrm{P}$ \\
\hline $2-3$ & 106 & 173 & $\begin{array}{l}\text { value } \\
-\end{array}$ \\
\hline$\geq 4$ & 15 & 21 & 0.007 \\
\hline
\end{tabular}

UI prevalence is not altered by the age at which first child delivered $\left(\mathrm{X}^{2}\right.$ value $-2.61, \mathrm{P}$ value -0.271$)$ (Table 2 ).

Table 2: Prevalence of UI in relation to age at first birth.

\begin{tabular}{|c|c|c|c|}
\hline $\begin{array}{l}\text { Age at } \\
\text { first } \\
\text { birth } \\
\text { (years) }\end{array}$ & $\begin{array}{l}\text { Urinary } \\
\text { incontinence + } \\
(n=135)\end{array}$ & $\begin{array}{l}\text { No } \\
\text { incontinence } \\
(n=247)\end{array}$ & \multirow[t]{2}{*}{$\begin{array}{l}X^{2} \\
\text { value } \\
-2.61\end{array}$} \\
\hline$<19$ & 40 & 61 & \\
\hline $20-29$ & 95 & 183 & \multirow{2}{*}{$\begin{array}{l}P \\
\text { value } \\
- \\
0.271\end{array}$} \\
\hline$\geq \mathbf{3 0}$ & 0 & 3 & \\
\hline
\end{tabular}

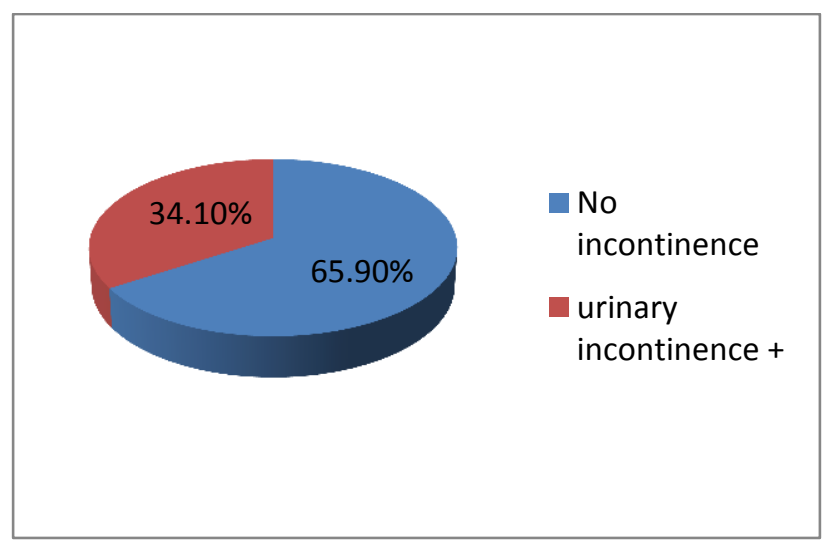

Figure 1: Prevalence of UI. 


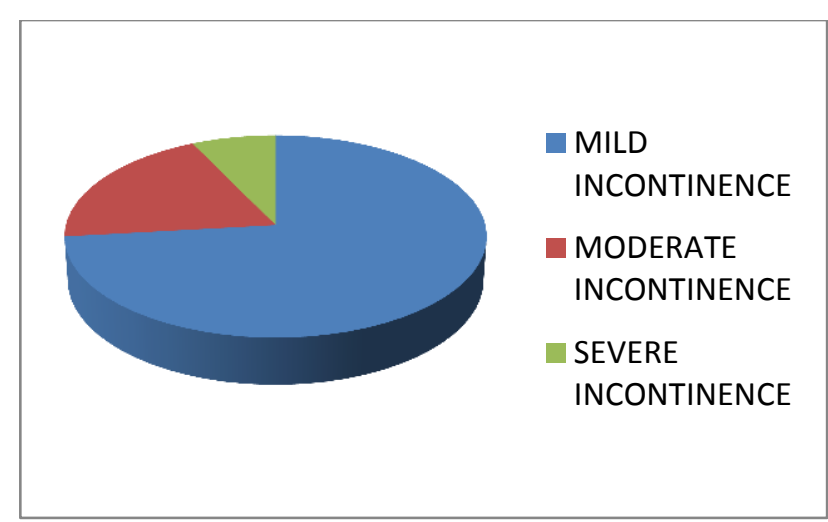

Figure 2: Distribution of UI by severity.

Gap between pregnancies have no influence on UI $\left(\mathrm{X}^{2}\right.$ value -3.28 , P value - 0.194) (Table 3 ).

Table 3: Prevalence of UI in relation to inter delivery interval.

\begin{tabular}{|c|c|c|c|}
\hline $\begin{array}{l}\text { Interval } \\
\text { between } \\
\text { delivery }\end{array}$ & $\begin{array}{l}\text { Urinary } \\
\text { incontinence + } \\
(\mathrm{n}=121)\end{array}$ & $\begin{array}{l}\text { No } \\
\text { incontinence } \\
(n=194)\end{array}$ & $\begin{array}{l}X^{2} \\
\text { value } \\
-3.28\end{array}$ \\
\hline$\leq 2$ years & 30 & 36 & \\
\hline $\begin{array}{l}3-5 \\
\text { years }\end{array}$ & 91 & 155 & \multirow{2}{*}{$\begin{array}{l}\mathrm{P}- \\
\text { value - } \\
0.194\end{array}$} \\
\hline $\begin{array}{l}6-9 \\
\text { years }\end{array}$ & 0 & 3 & \\
\hline
\end{tabular}

UI is significantly more prevalent in those with $\mathrm{BMI} \geq 30$ $\left(\mathrm{X}^{2}\right.$ value $-11.4, \mathrm{P}$ value -0.010$)($ Table 4$)$.

Table 4: Prevalence of UI in relation to BMI.

\begin{tabular}{|c|c|c|c|}
\hline BMI & $\begin{array}{l}\text { Urinary } \\
\text { incontinence } \\
+ \\
(n=138)\end{array}$ & $\begin{array}{l}\text { No } \\
\text { incontinence } \\
(n=266)\end{array}$ & \multirow{3}{*}{$\begin{array}{l}\mathrm{X}^{2} \\
\text { value } \\
-11.4\end{array}$} \\
\hline$<18.5$ & 5 & 18 & \\
\hline $18.5-24.99$ & 71 & 168 & \\
\hline $25-29.99$ & 50 & 71 & \multirow{2}{*}{$\begin{array}{l}\mathrm{P} \\
\text { value } \\
- \\
0.010\end{array}$} \\
\hline$\geq 30$ & 12 & 9 & \\
\hline
\end{tabular}

Waist circumference has no association with prevalence of UI ( $\mathrm{X}^{2}$ value $-0.821, \mathrm{P}$ value - 0.844) (Table 5). On comparing the mode of delivery, UI was higher in those who had vaginal delivery than those who had caesarean section $\left(\mathrm{X}^{2}\right.$ value $-4.09, \mathrm{P}$ value- 0.043) (Table 6).
Table 5: Prevalence of UI in relation to waist circumference.

\begin{tabular}{|llll|}
$\begin{array}{l}\text { Waist } \\
\text { circumference } \\
(\mathrm{cm})\end{array}$ & $\begin{array}{l}\text { Urinary } \\
\text { incontinence } \\
+ \\
(\mathrm{n}=138)\end{array}$ & $\begin{array}{l}\text { No } \\
\text { incontinence } \\
(\mathrm{n}=266)\end{array}$ & $\begin{array}{l}\mathrm{X}^{2} \\
\text { value }\end{array}$ \\
\hline$<75$ & 52 & 89 & - \\
\hline 75 to 79 & 68 & 143 & 0.821 \\
\hline 80 to 85 & 17 & 32 & $\begin{array}{l}\mathrm{P} \\
\text { value } \\
- \\
>85\end{array}$ \\
\hline
\end{tabular}

Table 6: Prevalence of UI in relation to mode of delivery.

\begin{tabular}{|llll|}
\hline $\begin{array}{l}\text { Mode of } \\
\text { delivery }\end{array}$ & $\begin{array}{l}\text { Urinary } \\
\text { incontinence }+\end{array}$ & $\begin{array}{l}\text { No } \\
\text { incontinence }\end{array}$ & $\begin{array}{l}\mathrm{X}^{2} \\
\text { value }-\end{array}$ \\
\hline $\begin{array}{l}\text { Vaginal } \\
\text { delivery }\end{array}$ & 106 & 170 & 4.09 \\
\hline $\begin{array}{l}\text { Caesarean } \\
\text { section }\end{array}$ & 29 & 77 & $\begin{array}{l}\text { P value } \\
-0.043\end{array}$ \\
\hline
\end{tabular}

Table 7: General health perception in woman with UI.

\begin{tabular}{|c|c|c|c|}
\hline $\begin{array}{l}\text { General } \\
\text { health } \\
\text { perception } \\
\text { (\% of } \\
\text { health } \\
\text { affection) }\end{array}$ & $\begin{array}{l}\text { Urinary } \\
\text { incontinence } \\
+\end{array}$ & $\begin{array}{l}\text { No } \\
\text { incontinence }\end{array}$ & \multirow{3}{*}{$\begin{array}{l}X^{2} \\
\text { value } \\
-152\end{array}$} \\
\hline $25 \%$ & 0 & 2 & \\
\hline $50 \%$ & 45 & 240 & \\
\hline $75 \%$ & 91 & 22 & \multirow{2}{*}{$\begin{array}{l}\mathrm{P} \\
\text { value } \\
- \\
0.000\end{array}$} \\
\hline $75 \%$ & 2 & 2 & \\
\hline
\end{tabular}

Those with UI had significantly more amount of health affection than those without incontinence $\left(\mathrm{X}^{2}\right.$ value 152, $\mathrm{P}$ value -0.000 ) (Table 7).

In mild incontinence group, $35-40 \%$ had role limitation and physical activity limitation. Up to $35 \%$ of women in mild UI group had emotional and sleep affection. In those with moderate incontinence, > 95\% had physical activity limitation and social limitation. More than $85 \%$ of women had role limitation and emotional affection in them. In those with severe incontinence, $90 \%$ had physical activity restriction, social limitation, emotional affection and sleep deprivation. $70 \%$ of women with severe UI had role limitation. 


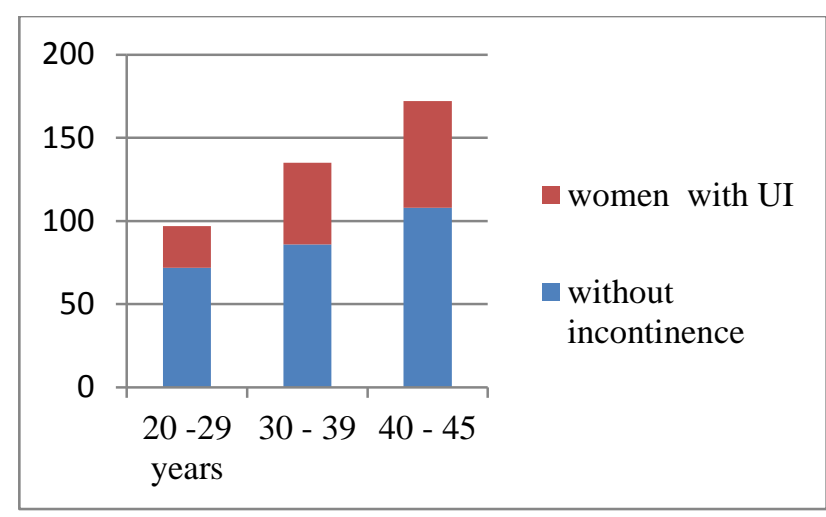

Figure 3: Prevalence of UI in different age groups.

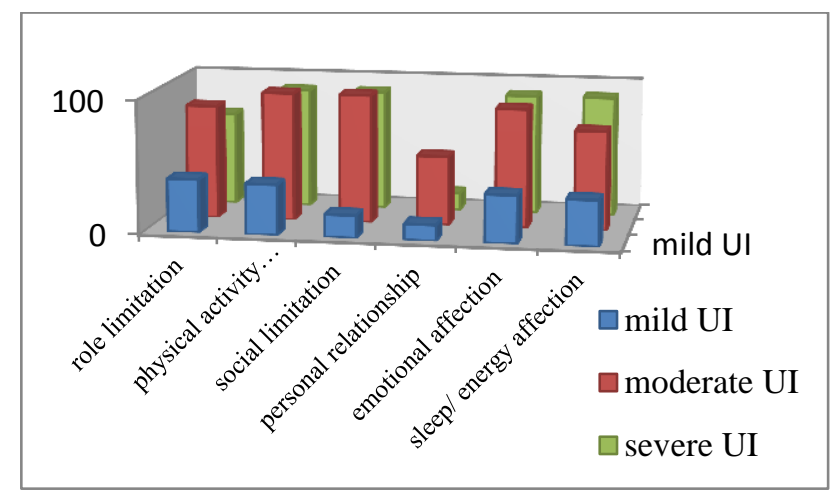

Figure 4: UI and quality of life affection.

\section{DISCUSSION}

The prevalence of UI was $34.1 \%$ in our study. Other studies also show higher prevalence of UI in adult population 17 to $53.4 \% .^{9-11}$ Because of the higher prevalence of UI, it is essential to evaluate its cause and to take possible preventive measures to reduce the incidence of UI.

The prevalence of UI increases with age. A study done among US women, showed that UI of moderate to severe degree affects $7 \%$ of women in the age of 20 to $39,17 \%$ in 40 to $59 \mathrm{yr}$ of age, $23 \%$ in 60 to $79 \mathrm{yr}$ of age, and $32 \%$ in $80 \mathrm{yr}$ of age. ${ }^{12}$ The reason is after menopause with decrease in hormonal levels, there is progressive decrease in muscle tone and decreased contractility of the urethral sphincter leading to UI. ${ }^{13,14}$

Similar to our study results several other study results show increased prevalence of incontinence in obese women. Townsend et al in 2007, compared relationship of BMI and incidence of UI in middle aged women. ${ }^{15}$ Compared to women with normal BMI, women of BMI $\geq$ $35 \mathrm{~kg} / \mathrm{m}^{2}$ had higher prevalence of all types of UI. Odds of having stress incontinence was 3.42 (95\% confidence interval [CI] 2.48-4.72), for urge incontinence it was 6.10 (95\% CI 3.11-11.98) and for mixed incontinence odds ratio was 5.60 (95\% CI 3.17-9.88). With increase in BMI, the associated increase in intra-abdominal pressure and intra-vesical pressure may be the cause for pelvic floor dysfunction. Various studies have documented improvements in UI after weight loss following bariatric surgery ${ }^{16-18}$ There is also higher prevalence $(16-68 \%)$ of fecal incontinence in obese women. ${ }^{19}$ With the measures to decrease weight following bariatric surgery, the prevalence of fecal incontinence decreased significantly. ${ }^{16}$ This association between obesity and urinary and fecal incontinence shows that weight loss in obese and overweight women is important aspect in preventing and treating them.

Similar to our study results, numerous other studies showed higher prevalence of UI in women who delivered vaginally. Gyhagen et al compared the prevalence of UI between women who delivered vaginally and by cesarean section. ${ }^{20}$ UI was $67 \%$ higher after a vaginal delivery (40.3\%) compared to women who had undergone caesarean section (28.8\%), (OR 1.67; 95\% CI 1.45-1.92). Follow up of women 10 years after delivery, showed that prevalence was $10.1 \%$ after vaginal delivery compared with $3.9 \%$ after caesarean section (odds ratio [OR] 2.75; 95\% CI 2.02-3.75). Another study by Rortveit et al comparing caesarean section with vaginal delivery also showed SUI was significantly associated with vaginal deliveries (OR 2.4). ${ }^{6}$

Vaginal delivery and higher parity increased the risk of both urinary and fecal symptoms due to pelvic floor dysfunction. ${ }^{21}$ Multiple logistic regression of persistent UI showed that compared to single vaginal delivery, women who had multiple deliveries had higher incidence of UI. ${ }^{22}$ Odds ratio is higher for increase in number of deliveries. Odds of UI was 1.36 (95\% CI- 1.06-1.74; P value- 0.015 ) in women who had 2 deliveries, in those with 3 deliveries had OR of 1.85 (95\% CI- $1.42-2.42$; P value $<0.001)$, whereas in those with four or more deliveries had OR of 2.16 (95\% CI- 1.57-2.97; P value < 0.001). Several studies evaluated the bladder-neck mobility using ultrasound after the first delivery. ${ }^{23}$ They showed that bladder-neck mobility was increased after vaginal delivery and unchanged after cesarean. Fritel et al, in their study showed that cesarean was significantly associated with a lower risk of SUI compared to normal delivery. ${ }^{24}$ It is not known whether by increasing the number of caesarean sections, the incidence of SUI could be decreased. Even reverse can be considered true that, women requiring cesarean have more inflexible connective tissue (lower incidence of SUI), leading to delayed cervical dilatation, requiring surgical intervention.

The KHQ is considered a complete questionnaire that assesses both the impact of incontinence in different aspects of quality of life. ${ }^{25,26}$ The International Continence Society classifies the questionnaire as highly recommendable to use in clinical research, mainly due to its popularity and for the fact of being already translated into and validated in other languages. ${ }^{27}$ 
In mild incontinence group, 35 - 40\% had role limitation and physical activity limitation. Up to $35 \%$ of women with UI had emotional and sleep affection. In those with moderate UI, > 95\% had social limitation and physical activity limitation. More than $85 \%$ of them also had role limitation and emotional affection. In those with severe incontinence, $90 \%$ had social limitation, physical activity restriction, emotional affection and sleep deprivation. $70 \%$ of women with severe UI had role limitation. Women in moderate and severe incontinence group had severe affection in all aspects of life. Grimby and colleagues assessed QoL using the Nottingham Health Profile Questionnaire among Swedish women aged 6584. This study suggested that, women with any form of UI experience more social isolation and more emotional disturbances than age-matched continent women. ${ }^{28}$

Assessment of QoL among women with UI has been studied preoperatively and 6 months following surgery. ${ }^{29}$ $93 \%$ of women with SUI had interference with physical activity prior to surgery, which has reduced to $17 \%$ at 6 months after surgery. Also $63 \%$ of them had problems in sexual activity, which has reduced to $27 \%$ at 6 months after surgery. $63 \%$ had incontinence with sexual intercourse, reduced to $11 \%$ after surgery. $77 \%$ had interference with social relationships, reduced to $13 \%$ after surgery. So, definitive treatment for UI helps in improving their QoL. The present study demonstrated that UI presented a negative impact on QoL in these women. These results emphasize the need of healthcare professionals to address this problem especially among women in reproductive age group.

\section{CONCLUSIONS}

The prevalence of urinary incontinence was $34.1 \%$. Urinary incontinence had higher impact on emotional and social well-being. Awareness has to be created about available treatment options among women.

Funding: No funding sources Conflict of interest: None declared

Ethical approval: The study was approved by the Institutional Ethics Committee

\section{REFERENCES}

1. Abrams P, Cardozo L, Fall M, Griffiths D, Rosier P, Ulmsten $\mathrm{U}$, et al. The standardization of terminology in lower urinary tract function: report from the Standardization Sub-committee of the International Continence Society. Neurourol Urodyn. 2002;21(2):167-78.

2. Buckley BS, Lapitan MC. Epidemiology Committee of the Fourth International Consultation on Incontinence, Paris, 2008. Prevalence of urinary incontinence in men, women, and children - current evidence: findings of the Fourth International Consultation on Incontinence Urology. 2010;76:265-70.
3. Staskin DR: Age-related physiologic and pathologic changes affecting lower urinary tract function. Clin Geriatr Med. 1986;2:701-10.

4. McGrother C, Resnick M, Yalla SV, KirschnerHermanns R, Broseta E, Mullar $\mathrm{C}$ et al. Epidemiology and etiology of urinary incontinence in the elderly. World Journal of Urology. 1998;16(1):S3-S9.

5. Hunskaar S, Arnold EP, Burgio K, Diokno AC, Herzog AR, Mallett VT. Epidemiology and natural history of urinary incontinence. Int Urogynecol J Pelvic Floor Dysfunct. 2000;11(5):301-19.

6. Rortveit G, Daltveit AK, Hannestad YS, Hunskaar S. The Norwegian EPINCONT Study. Urinary Incontinence after Vaginal Delivery or Cesarean Section. N Engl J Med. 2003;348(10):900-7.

7. Sandvik H, Hunskaar S, Seim A, Hermstad R, Vanvik A, Bratt H. Validation of a severity index in female urinary incontinence and its implementation in an epidemiological survey. $\mathrm{J}$ Epidemiol Community Health. 1993;47:497-9.

8. Kelleher $\mathrm{CJ}^{1}$, Cardozo LD, Khullar V, Salvatore S. A new questionnaire to assess the quality of life of urinary incontinent women. Br J Obstet Gynaecol. 1997;104(12):1374-9.

9. Irwin DE, Milsom I, Hunskaar S, Reilly K, Kopp Z, Herschorn $S$ et al. Population-based survey of urinary incontinence, overactive bladder, and other lower urinary tract symptoms in five countries: results of the EPIC study. Eur Urol. 2006;50(6):1306-14.

10. Hunskaar S, Lose G, Sykes D, Voss S. The prevalence of urinary incontinence in women in four European countries. BJU Int. 2004;93(3):324-30.

11. Markland AD, Richter HE, Fwu C-W, Eggers P, Kusek JW. Prevalence and Trends of Urinary Incontinence in Adults in the United States, 2001 to 2008. The Journal of urology. 2011;186(2):589-93.

12. Nygaard I, Barber MD, Burgio KL, Kenton $\mathrm{K}$, Meikle S, Schaffer J, et al. Prevalence of symptomatic pelvic floor disorders in US women. JAMA. 2008;300:1311-6.

13. Danforth KN, Townsend MK, Lifford K, Curhan GC, Resnick NM, Grodstein F. Risk factors for urinary incontinence among middle-aged women. Am J Obstet Gynecol. 2006;194:339-45.

14. Luber KM. The definition, prevalence, and risk factors for stress urinary incontinence. Rev Urol. 2004;6:S3-9.

15. Townsend MK, Danforth KN, Rosner B, Curhan GC, Resnick NM, Grodstein F. Body mass index, weight gain, and incident urinary incontinence in middleaged women. Obstet Gynecol. 2007;110:346.

16. Burgio KL, Richter HE, Clements RH, Redden DT, Goode PS. Changes in urinary and fecal incontinence symptoms with weight loss surgery in morbidly obese women. Obstet Gynecol. 2007;110(5):103440 . 
17. Greer WJ, Richter HE, Bartolucci AA, Burgio KL. Obesity and pelvic floor disorders: a systematic review. Obstet Gynecol. 2008;112:341-9.

18. Subak LL, Wing R, West DS, Franklin F, Vittinghoff E, Creasman JM, et al. Weight loss to treat urinary incontinence in overweight and obese women. N Engl J Med. 2009;360(5):481-90.

19. Poylin V, Serrot FJ, Madoff RD, Ikramuddin S, Mellgren A, Lowry AC, et al. Obesity and bariatric surgery: a systematic review of associations with defecatory dysfunction. Colorectal Dis. 2011;13(6):92-103.

20. Gyhagen M, Bullarbo M, Nielsen T, Milsom I. The prevalence of urinary incontinence 20 years after childbirth: a national cohort study in singleton primiparae after vaginal or caesarean delivery. BJOG. 2013;120:144-51.

21. Kepenekci I, Keskinkilic B, Akinsu F, Cakir P, Elhan AH, Erkek AB, et al. Prevalence of pelvic floor disorders in the female population and the impact of age, mode of delivery, and parity. Dis Colon Rectum. 2011;54:85-94.

22. MacArthur C, Glazener CM, Wilson PD, Lancashire RJ, Herbison GP, Grant AM. Persistent urinary incontinence and delivery mode history: a six-year longitudinal study. BJOG: An International Journal of Obstetrics \& Gynaecology. 2006;113:218-24.

23. Toozs-Hobson P, Balmforth J, Cardozo L, Khullar $\mathrm{V}$, Athanasiou S. The effect of mode of delivery on pelvic floor functional anatomy. Int Urogynecol J Pelvic Floor Dysfunct. 2008;19(3):407-16.
24. Fritel X, Fauconnier A, Levet C, Benifla J-L. Stress urinary incontinence 4 years after the first delivery: a retrospective cohort survey. Acta Obstetricia et Gynecologica Scandinavica. 2004;83(10):941-5.

25. Hebbar S, Pandey H, Chawla A. Understanding King's Health Questionnaire (KHQ) in assessment of female urinary incontinence. Int J Res Med Sci. 2015;3(3):531-8.

26. Margolis MK, Vats V, Coyne KS, Kelleher C. Establishing the content validity of the King's Health Questionnaire in men and women with overactive bladder in the US Patient. 2011;4(3):17787.

27. Abrams P, Cardozo L, Khoury S, Wein, A, editors. Incontinence. 3rd ed. Plymouth: Plymbridge. Symptom and quality of life assessment. 2001;267315.

28. Grimby A, Milsom I, Molander U, Wiklund I, Ekelund P: The influence of urinary incontinence on the quality of life of elderly women age ageing. 1993;22:82.

29. Ward K, Hilton P. Prospective multicentre randomised trial of tension free vaginal tape and colposuspension as primary treatment for stress incontinence. United Kingdom and Ireland TensionFree Vaginal Tape Trial Group. BMJ. 2002;325:6773.

Cite this article as: Poomalar GK, Priyadharshini $M$. Prevalence of urinary incontinence in reproductive women and its impact on quality of life. Int J Reprod Contracept Obstet Gynecol 2015;4:1353-8. 